\title{
Da caixa de sugestões às mídias digitais: o fazer comunicacional pelo Boticário
}

Patrícia M. Pérsigo e Maria Ivete Trevisan Fossá

\section{Resumo:}

Este artigo apresenta as transformações que as tecnologias da informação e da comunicação provocam no contexto corporativo. As organizações modernas passam a contar com uma gama cada dia maior de ferramentas digitais, portanto a gestão da comunicação precisa elaborar estratégias promovendo posicionamento, bem como canais de relacionamento organizacionais, também, no ciberespaço. Através de uma pesquisa bibliográfica e estudo da utilização das mídias digitais pela empresa O Boticário, buscase delinear a realidade organizacional no contexto dessas transformações. A partir deste entendimento, propõe-se uma reflexão sobre o uso dessas mídias respeitando as características da cultura organizacional e dos públicos envolvidos.

\section{Palavras Chave:}

Comunicação organizacional, mídias digitais, relacionamento organizacional, gestão da comunicação

\begin{abstract}
:
This article discusses the changes inflicted by communication and information technology on the context of corporations. Modern organizations have been using a large number of digital tools, therefore communication management needs to develop strategies to promote the openning of organizational relationship channels also in cyberspace. Through literature research and studying the uses of digital media by $\mathrm{O}$ Boticário, we investigate such organizational reality in the context of the mentioned transformations. From this point of view, we propose a reflection on the use of digital media taking into account the characteristics of organizational culture and the audience involved as well.
\end{abstract}

\section{Keywords:}

Organizational communication, digital media, communication management.

\section{Do blog: Mamie Bella (1)}

Letícia acabou de entrar no sexto mês de gravidez de Thiago. É jornalista e adora maquiagens, cremes e todos esses cosméticos. Escreve no Blog Notas de Beleza. Aqui ela fala sobre as sensações de uma mulher grávida pela primeira vez.

- [...] E foi muito gostoso assistir depois: eu percebi duas mulheres espirrando felicidade por todos os poros, babonas que só com os seus rebentos que estão por vir. Mas eu tenho cá pra mim que o meu filhote chega primeiro. Não me perguntem por quê. É cisma de mãe...

Lyanne adora andar descalça na grama, aprender sobre novas culturas e sentir a natureza. Blogueira do Vida de Viajante, escreve sobre os detalhes de sua gravidez. 
- Lembre-se de que nessa fase de 'novidades' para nós, tudo pode ser um risco para o bebê, então, não custa nada perguntar. Cuide de sua saúde, alimente-se bem, coma frutas e verduras e beba muito, mas muuuito líquido.

Renata está grávida de 8 meses da Chiara. É atriz, redatora e tradutora. Comanda o blog Bicho Solto e colabora com suas histórias para o "Dedinhos de Moças".

- O bacana foi que, dessa vez, conseguimos viver o que não vivemos há quatro anos atrás. [...] a palavra de ordem foi tranqüilidade, ambiente sereno, nada de ansiedade, muito carinho, muita confiança no ar. Ao meu lado, somente rostos queridos, que me encorajavam e me davam força quando eu mais precisava.

\section{Do blog: Eu faço o mundo mais belo}

22 de maio: Dia da Biodiversidade.

Uma excelente oportunidade para uma reflexão e reavaliação das nossas ações sobre a sustentabilidade do planeta. Tome decisões e tenha atitudes para ajudar a cuidar da nossa biodiversidade:

Pela manhã, ao lavar o rosto, barbear-se, escovar os dentes, tomar banho... lembre-se que a água é um bem precioso, reduza o tempo no banho e feche a torneira quando não estiver utilizando! Prepare seu café da manhã com alimentos orgânicos e frutas compradas em sua região, que não precisam ser transportados de longa distância, diminuindo a emissão de gases responsáveis pelo aquecimento global. Antes de sair de casa, confira se todos os aparelhos eletrônicos estão desligados e economize energia. Para ir ao trabalho ou para escola, caminhe, use a bicicleta ou utilize o transporte coletivo. Se for ao mercado, leve sua sacola. Ao lavar a louça encha a pia com água e enxágüe rapidamente. Promova uma conversa sobre esse assunto, comente sobre as boas atitudes que você irá tomar nesse dia e estimule-os a fazer o mesmo! E o principal, lembre-se que todo dia é dia de cuidar da natureza! Queremos saber como foi essa experiência! Conte para nós o que você fez nesse dia, que outra idéia teve e como foram as atividades na sua escola para comemorar o dia da biodiversidade.

Num julgamento apressado, qualquer leitor pode entender estes relatos apenas como publicações de cunho pessoal ou a divulgação de experiências cotidianas. Entretanto, os blogs Mamie Bella, a beleza da mulher antes e depois do parto! (2) e Eu faço um mundo mais belo (3), são campanhas lançadas pela empresa O Boticário (4) com objetivos mercadológicos e institucionais publicizados não somente através de folders, cartazes, vídeo tapes, jingles entre outros, mas principalmente através das possibilidades viabilizadas pelo ciberespaço (5).

No primeiro caso, observam-se dicas de saúde e beleza para gestantes e, no segundo, a preocupação com o desenvolvimento da consciência ambiental. A utilização de um blog representa a possibilidade de troca de opiniões, dicas e relatos, proporcionando a participação dos leitores com um ritmo rápido de respostas. Inicialmente, os blogs surgiram como diários particulares e individuais publicados on-line distante de objetivos empresariais ou finalidades comerciais. E hoje, publicar um blog corporativo configura-se como uma inovação. (ORDUÑA et. al, 2007)

Analisando cuidadosamente os blogs em questão, a partir deles também se disponibilizam links para outras possibilidades de comunicação, divulgação ou download de conteúdos aos internautas, como por exemplo: Orkut, Twitter,Youtube, Blip.fm, Flickr. Para entender melhor a utilização das mídias digitais (6) apresentadas é necessário um estudo mais detalhado sobre os usos e apropriações que vêm ocorrendo, 
bem como o contexto e os objetivos almejados pela organização que emprega esses espaços digitais na sua comunicação organizacional. Com o objetivo de conectar as pessoas aos ideais de beleza $\mathrm{O}$ Boticário pratica a comunicação corporativa integrando as tradicionais ferramentas e canais de relacionamento da mídia de massa com as mídias digitais.

A partir de uma pesquisa bibliográfica, estudo do plano de atendimento ao consumidor O Boticário (7), bem como da utilização das mídias digitais no fazer da comunicação organizacional da empresa em questão, o presente artigo busca delinear a realidade organizacional no contexto das transformações tecnológicas. A partir deste entendimento, pretende-se refletir sobre o uso dessas mídias respeitando as características da cultura organizacional e dos públicos envolvidos.

\section{As organizações no contexto das transformações tecnológicas}

Castells (1999) afirma que se vive uma dinâmica transformação da nossa cultura material para um paradigma tecnológico, embasado na tecnologia da informação. Essa mudança envolve e influencia, diretamente ou indiretamente, empresas, indivíduos, meios de comunicação, instituições e a sociedade em geral. O cenário atual, em decorrência de alterações não só tecnológicas, mas também políticas, culturais e econômicas, levam as organizações a uma necessidade de adaptação. Ou seja, são impelidas a assumirem diferenciadas e inovadoras estratégias, atitudes mais transparentes e uma postura mais aberta ao diálogo com seus públicos. Cada vez mais a capacidade de flexibilização e readaptação de estratégias e políticas empresariais são imperativos na conquista da postura competitiva para a sobrevivência no mercado globalizado.

$\mathrm{Na}$ atualidade destaca-se a presença e o uso das tecnologias que agem sobre a informação, potencializando a sua penetrabilidade em várias esferas sociais, da existência individual ou coletiva, para uso particular, profissional ou organizacional. Desta forma, a sociedade torna-se interconectada pelas redes telemáticas, marcada pela flexibilidade não só de processos, mas também das organizações e instituições, convergindo para um sistema altamente integrado operacionalizado pelo computador. Esta é a sociedade em rede em que computadores e sistemas de comunicação organizam-se como extensões da mente humana segundo Castells (1999).

A globalização e o advento das tecnologias da informação e da comunicação se apresentam como fatores preponderantes na mudança de comportamento organizacional, num contexto em que seu relacionamento não se limita mais ao antigo público interno, externo e misto. $\mathrm{Na}$ sociedade em rede, as interações acontecem independente do tempo e do espaço. Nesse contexto, as empresas enfrentam diversos fatores como: a concorrência cada dia mais acirrada, a mudança no perfil do consumidor e a grande variedade de produtos ofertados. Além disso, na contemporaneidade, a compra não necessita mais ser realizada presencialmente, é possível realizá-la através da internet. Desta forma, os consumidores ampliam sua opção de escolha, adotando novos e diversificados critérios para sua compra. Nesse sentido deve-se considerar que "tudo isso envolve necessariamente a adoção de novas e renovadas técnicas produtivas e de trabalho, assim como de marketing, além da mudança de mentalidade de empresários, técnicos, assalariados e consumidores" (IANNI 2002: 189).

Conforme Echeverria (2004), hoje uma pequena organização local pode adotar um comportamento de gestão global. Esse cenário possibilita operar localmente pensando globalmente. A partir desta realidade é necessário que as corporações reprogramem seu posicionamento e busquem se destacar também no mercado global. Para isto, precisarão repensar suas estratégias de comunicação e diversificá-las, buscando a inovação. De forma geral, pode-se inferir que as organizações que conseguirem acompanhar esta dinâmica e que integrarem ao seu plano de comunicação diferenciados canais de interação e 
relacionamento serão consideradas competitivas e estarão aptas a prosperar.

Organizações bem-sucedidas são aquelas capazes de gerar conhecimentos e processar informações com eficiência; adaptar-se a geometria variável da economia global; ser flexível o suficiente para transformar seus meios tão rapidamente quanto mudam os objetivos sob o impacto da rápida transformação cultural, tecnológica e institucional; e inovar, já que a inovação torna-se a principal arma competitiva (CASTELLS, 1999: 233).

Tendo como contexto a sociedade em rede, percebe-se que exercer a comunicação organizacional tornase mais complexo. As mídias digitais possibilitam novas formas de relacionamentos, independente da questão espaço-temporal, entre organização e consumidores, fornecedores, colaboradores, imprensa, comunidade e concorrentes.

A comunicação se destaca como um setor estratégico de forma a agregar valor e facilitar os processos interativos e as mediações. Esse caráter estratégico está no fato de que no ciberespaço é livre a circulação de mensagens e o público organizacional não é mais apenas receptor de fluxos informacionais. Agora ele torna-se ora receptor e ora emissor, atuando como um "editor-coletor-distribuidor" de informações (LEMOS, 2004). Assim, as organizações passam a dividir o poder de disseminar mensagens com seus próprios públicos que também participam do processo de produção de informações e se manifestam através da rede. Nesse sentido, pode-se dizer que na atualidade a comunicação organizacional deve contemplar, também, a comunicação virtual (8).

As organizações modernas contam com uma gama cada dia maior de ferramentas digitais, o que evidencia que a gestão dessa comunicação não pode deixar de lado a necessidade de planejar estratégias com vistas ao seu posicionamento, também, no espaço virtual. Castells (1999), ao comentar sobre a transformação ocorrida nas organizações, atribui à evolução da tecnologia a potencialização da mudança ocorrida neste âmbito.

A revolução digital transforma a sociedade levando-a a um novo processo de interação social, uma vez que as telecomunicações, o rádio, a televisão, a imprensa e os demais meios de comunicação se adaptam a essa configuração. Os veículos de comunicação de massa reconfiguram-se e integram-se às possibilidades de interação digital, já que agora esse processo se dá para segmentos e, até, nichos de públicos. Resumidamente, pode-se dizer que o processo de difusão de mensagens centralizado, unidirecional e vertical, se atualiza e se integra a uma nova mídia interativa, multimidial, descentralizada e diversificada.

\section{As mídias digitais e seus usos na comunicação organizacional do Boticário}

\section{A representação no ciberespaço}

O Boticário, empresa paranaense que atua no mercado nacional e internacional, configura-se como o objeto empírico deste artigo. A escolha foi feita a partir da observação da existência de várias estratégias de comunicação organizacional que utilizam as mídias digitais. Alguns exemplos são: blog Mamie Bella com links para outros espaços digitais - Orkut, Twitter, Youtube, Blip.fm, Flickr; blog Eu faço um mundo mais belo - com vídeos no YouTube ou em CD-Rom e o Tweetquero - uma aplicação baseada no twitter onde os internautas respondem o que querem ganhar de presente. Outro motivo é o fato da empresa contar com o "Centro de Relacionamento ao Cliente" (CRC). Neste centro são planejadas diversas ações de relacionamento além do monitoramento de blogs e comunidades do Orkut que abordem assuntos de interesse da empresa.

A organização, através da sua homepage corporativa, marca a sua presença e posiciona-se no ciberespaço. 
Nessa representação são disponibilizadas diversas informações como: o histórico da empresa, sua visão e valores, política de recursos humanos, franquias - onde localizá-las, como abrir uma, qual a sua proposta - lojas no mercado internacional, informações sobre a fundação $O$ Boticário, projetos de Responsabilidade Social, Sala de Imprensa, programas internos de preservação ao meio ambiente e um link especial para atendimento ao cliente. Echeverria (2004), ao falar do terceiro entorno (9), destaca a importância da representação nesse cenário virtual. $\mathrm{O}$ autor diz que:

para estar na internet tem que se construir uma página correspondente na web, que é uma representação de alguém, empresa ou organização em si. Atua-se através dessa imagem tecnológica. O importante é que para atuar no terceiro entorno é imprescindível construir diversas representações e fazê-las bem (ECHEVERRIA, 2004: 67) (10).

Conforme o autor, para atuar nesse cenário é preciso fazer-se representar e fazer bem, ou seja, oferecer diversidade e possibilidade de fácil acesso a informações, canais de diálogo e até dados que o público nem espera encontrar. No caso apresentado, O Boticário configura-se como autogerenciador de sua visibilidade (11), uma vez que para divulgar sua existência não necessita estar sujeito aos filtros e condições de produção dos tradicionais meios de comunicação de massa. Através da internet tem-se a possibilidade de realizar ações e planejar estratégias para segmentos e até nichos de públicos. Utilizandose de recursos multimídia, a organização comunica-se com seu público de forma personalizada, interativa e atraente, levando-o a retornar àquela página como fonte de satisfação de suas necessidades, como no caso do Tweetquero (12). Baseado no Twitter os participantes respondem a pergunta: o que você quer ganhar de presente? A aplicação dessa mídia digital é utilizada como uma lista pública de presentes, linkados ao perfil do usuário no twitter. Apesar de ser um aplicativo de livre acesso, a maioria dos presentes referem-se a produtos O Boticário.

Há algum tempo, a visibilidade pública de uma organização estava condicionada pelos critérios da mídia de massa, existia uma limitação de espaço, além do custo, algumas vezes incompatível com a realidade organizacional. Hoje, através das mídias digitais, é possível a organização expor-se com "suas próprias palavras" (KEGLER, 2008) disponibilizando informações diversas, a fim de estimular os processos de interação.

Embora exista uma tendência das empresas em utilizar a internet como forma de incrementar as suas vendas, o primordial que se apresenta é a possibilidade do estabelecimento do diálogo com os diversos públicos organizacionais. Na atualidade, não basta à organização ter visibilidade, é necessário procurar canais e estabelecer estratégias que favoreçam a interação com esses públicos.

\section{Mídias digitais e as possibilidades de interação}

A utilização das mídias digitais simboliza uma abertura a novas possibilidades de interação aproximando o público consumidor da organização e, também, do próprio processo de produção. Como nos exemplos citados (Mamie Bella e Eu faço um mundo mais belo), percebe-se que a utilização desses blogs tem como objetivo a potencialização das interações organizacionais, estimulando relacionamentos mercadológicos e institucionais respectivamente. Conforme estabelecido no plano de Relacionamento com o Consumidor(CRC), uma das preocupações da empresa é incentivar o consumidor viver a experiência dentro das lojas. Ou seja, O Boticário utiliza esses espaços digitais para aproximar-se e construir relacionamentos com seus públicos, também com vistas à interação face a face. A existência de estratégias de comunicação digital não exclui outras formas de comunicação, mas, sim, as integram.

Trazer informações, dicas, orientações sobre saúde na gravidez e relatos de gestantes caracterizam-se como vínculos que se estabelecem entre esse nicho de mercado e O Boticário. Ou seja, além de promover 
sua nova linha de produtos para gestantes, através do blog se dá uma interação mútua, onde o público e a organização constroem sua relação de comunicação. Primo (2007) é o autor que estabelece o conceito de interação mútua mediada pelo computador (13). A interação mútua pode ser caracterizada em: descontínua (ocorrendo em espaços de tempo), sincrônica (através de uma interação lógica dos fatos), recorrente (os fatos são base para relacionamentos futuros) e recíproca (um responde ao outro para manter a relação). O autor ainda aprofunda este pensamento destacando a importância da força do relacionamento, o grau de proximidade dos interagentes, a confiança no outro e o comprometimento dos indivíduos. Conforme estabelecido no CRC, O Boticário propõe-se a responder e-mails em até $24 \mathrm{~h}$, contatos telefônicos em até 30 segundos e cartas em até uma semana (14). A agilidade nas respostas organizacionais, o conteúdo divulgado, o feedback nas solicitações de informações, o respeito às opiniões diversas, são alguns fatores que atuarão como valores de escolha dos públicos ao decidir interagir com determinada empresa.

No blog Mamie Bella, observa-se a existência de mensagens tanto positivas quanto negativas, algumas vezes discordando do conteúdo publicado e assim, trocando experiências e sugestões. Médicos, nutricionistas, fisioterapeutas, mães, pais, mulheres e homens compartilham seus conhecimentos sobre os assuntos abordados, processo que se caracteriza como um exemplo de inteligência coletiva. Para Levy (1999), o ciberespaço e as tecnologias ajudam na circulação do saber. Circulação denominada de Inteligência Coletiva, que para o autor é "uma inteligência distribuída em todas as direções, valorizada sem cessar, coordenada em tempo real, e que chega a uma valorização e mobilização efetiva de competências" (1999: 28). Ainda nesse sentido, Lemos (2004) complementa explicando que o ciberespaço tipifica-se como esse ambiente de discussões pluralistas, facilitando o intercâmbio entre diversos conhecimentos e gerando laços comunitários. Ou seja, são diferentes competências que geram um conhecimento coletivo reforçando o elo entre os públicos.

Do ponto de vista mercadológico, as mídias digitais são estratégicas no que se refere ao público que as freqüenta: são audiências altamente segmentadas e, em geral, são visitantes e compradores habituais dos produtos expostos e informações divulgadas ali (ORDUÑA et. al, 2007). No caso do Mamie Bella, o público tem a possibilidade de se antecipar ao próprio lançamento do produto na mídia de massa atuando como influenciadores na decisão de compra e divulgadores desses produtos tanto na internet quanto no mundo físico.

No blog Eu faço um mundo mais belo! se constata outro segmento de público interagindo. Professores, pais, educadores, ambientalistas, ativistas e jovens têm a oportunidade de compartilhar conhecimento e aprender com o conteúdo disponibilizado. Mais uma vez, a partir da utilização dessa mídia, a organização promove a circulação do saber, o compartilhamento de conhecimentos e, por conseguinte, um processo de inteligência coletiva. Além disso, esse blog também é instrumento de divulgação dos projetos de responsabilidade ambiental do Boticário. Assim, a organização demonstra, estrategicamente, que além de objetivos econômicos, ao mesmo tempo, se preocupa e se responsabiliza com o meio em que atua, promovendo ações em benefício de todos. Nesse sentido, as mídias digitais colaboram na construção da imagem organizacional, destacando práticas que geram credibilidade, elemento tão importante na busca por relacionamentos mais sólidos.

A partir dos posts enviados, a empresa responde dúvidas, divulgando e convidando os internautas a participarem de ações específicas de seus projetos. O fato dessas mídias serem utilizadas com objetivos além da venda propriamente dita, não quer dizer que ela seja esquecida. No blog Eu faço um mundo mais belo! , por exemplo, são discutidas questões relativas ao consumo consciente em relação ao dia dos namorados. Isto é, a organização pode promover o debate aliando questões financeiras, como o consumo, à responsabilidade ambiental e o presente que será adquirido na próxima data comemorativa. 
Com o advento das tecnologias digitais, principalmente da internet, os consumidores deixaram a característica da passividade e assumiram uma postura mais exigente, curiosa e participativa.

O poder de espalhar novidades das "multidões inteligentes" e a busca dos clientes por informações nos websites das empresas estão formando a "Geração C". Essa denominação é aplicada por muitos especialistas e gurus de marketing e significa: "Geração Criatividade e Conteúdo": os clientes não querem apenas consumir os produtos, querem também participar da criação, dar sugestões de uso e interagir com outros clientes ou com a empresa. Antigamente as empresas pediam para seus clientes: "escute, assista, veja e compre!". Atualmente as empresas devem pedir: “crie, produza, participe, espalhe e compre!" (CIPRIANI, 2008: 20).

A interação através desses espaços digitais também vem facilitar a identificação de necessidades latentes e a avaliação de práticas organizacionais ou até mesmo a possibilidade de realização de testes piloto. É prática recorrente nas organizações o controle da qualidade de produtos e serviços, mas, neste artigo, quer se enfatizar a contribuição que as opiniões e manifestações dos públicos através dessas mídias podem contribuir na eficiência organizacional. Desta forma, ampliam-se as possibilidades de satisfação das necessidades dos públicos estratégicos.

Segundo Fortes (2003: 250) "os dados coletados ajudam a estabelecer estratégias promocionais sob medida e processos de relacionamento que atendam exatamente aos anseios dos públicos." Ainda nesse sentido, o autor ressalta a redução de custo que as mídias digitais proporcionam, tendo em vista os vários esforços envolvidos nas estratégias de divulgação institucionais ou mercadológicas através da mídia de massa (contatos via fax, ligações telefônicas, utilização do correio para envio de materiais, entre outros).

O Boticário também se configura como um exemplo de monitoramento das opiniões manifestadas nas mídias digitais. Esta prática representa maturidade organizacional, quando a empresa preocupa-se não somente em divulgar e vender seus produtos, mas também em conhecer as percepções de seus públicos a respeito de suas práticas. Como já foi mencionado anteriormente, por algum tempo o relacionamento com o público externo configurava-se como uma comunicação unidirecional. Hoje, com as possibilidades de interação através desses espaços, é possível que se estabeleça uma comunicação mais simétrica.

O modelo simétrico de duas mãos trata do entendimento e a compreensão mútua entre a organização e seus públicos, por isso é considerado um relacionamento ideal, ético e justo. Ao contrário da comunicação assimétrica, onde é mais comum a prática de estratégias meramente informativas, no modelo simétrico a organização se abre à comunicação bidirecional. Ou seja, tanto a organização quanto os públicos se comunicam, interagem e manifestam-se de forma a construir conjuntamente um relacionamento (GRUNIG e HUNT, 2003). Neste sentido percebe-se semelhança entre o modelo simétrico e a proposta de Primo (2007) sobre a interação mútua. A concepção de Alex Primo representa o modelo simétrico, agora mediado pelo computador.

Se por vezes as organizações preocupavam-se com os altos custos envolvidos na divulgação de suas ações na mídia de massa, agora, é possível interagir com seu segmento com custo reduzido. O Boticário, através da empresa E-life (15), trabalha com o monitoramento das manifestações de consumidores e demais públicos em blogs e outros espaços digitais. Com as informações obtidas em uma comunidade do Orkut a empresa pôde justificar o término da produção de um produto. Uma consumidora e participante da comunidade Órfãos do One of us (perfume produzido pela empresa) recebeu em sua caixa de e-mails a explicação do porquê da descontinuidade na produção do perfume. A internauta publicou a resposta na comunidade e demonstrou-se surpresa pelo fato de não ter se dirigido diretamente a empresa e mesmo assim ter recebido uma resposta. Suas palavras foram: "A Empresa mostrou seriedade com o consumidor (...)". Orduña et. al (2007) comenta que neste cenário os internautas podem atuar como propagadores da 
mensagem organizacional a outros grupos de pessoas. Como no caso acima, a opinião da consumidora deixa de representar a divulgação do produto e passa a caracterizar-se como recomendação, além de auxiliar na construção da imagem e reputação da empresa em questão.

Nos blogs citados anteriormente, O Boticário também disponibiliza links para o YouTube, a plataforma musical Blip.fm e álbuns de fotos no Flickr (16). Como diz Fortes (2003),

na comunicação virtual a informação objetiva, às vezes, não é suficiente para conquistar o explorador; precisa valer-se de propostas alternativas, como jogos e entretenimento, ou servir de simples "passagem" a sites bem configurados e completos (FORTES, 2003: 249).

Assim, a organização tem a possibilidade de representar-se em outras mídias, ou seja, ter contato com outros nichos de públicos (pessoas que utilizam o Blip.fm e o Flickr). Através de elos criados nesses ambientes, pode haver a recomendação de produtos ou informações que levarão outros internautas ao site da empresa.

A utilização dessas mídias significa a presença e oportunidade de diálogo organizacional não só através da mídia de massa, mas em um espaço onde é o próprio internauta que escolhe a informação que deseja. Por este motivo, a atuação empresarial ultrapassa as fronteiras do seu segmento de atuação e traz para o ciberespaço outras informações, como nos exemplos adotados, dicas de beleza para gestantes e informações sobre o meio ambiente. Através desses canais digitais de diálogo e relacionamento se abrem novas possibilidades de atuação e presença organizacional. No blog "Eu faço o mundo mais belo" são freqüentes as solicitações de escolas, ONG's, ambientalistas e indivíduos, interessados no assunto, pelos materiais divulgados para a utilização em seu dia-a-dia, profissional ou pessoal.

Sob a ótica empresarial, a utilização desta mídia para tratar de um assunto tão relevante na sociedade contemporânea, trabalha ao mesmo tempo na construção de uma consciência ambiental e, também, na divulgação das ações de responsabilidade social que levam o nome O Boticário. Através do ciberespaço, as organizações podem diversificar seus canais de divulgação oferecendo conteúdo relevante, atual e coerente com as práticas corporativas, conquistando multiplicadores de suas ações e, conseqüentemente, de sua identidade institucional. Desta forma, os públicos estratégicos passam a levar a marca da empresa vinculada a assuntos que vão além de uma estratégia meramente mercadológica.

\section{Mídias digitais como estratégias: considerações e ponderações}

Os exemplos citados e as possibilidades elencadas demonstram a profunda transformação que as tecnologias da informação e da comunicação trazem para as organizações. No caso apresentado são inegáveis as vantagens usufruídas pelo Boticário. Banco de dados, espaço para divulgação de campanhas e produtos, possibilidade de construção de uma imagem organizacional, visibilidade, além de fonte de pesquisa de satisfação e de mercado. Desta forma, demonstrou-se que as mídias digitais são canais de comunicação e relacionamento que podem, sim, ser utilizados de forma estratégica.

Ao mesmo tempo em que estas mídias se proliferam também se observa uma precaução por parte dos profissionais de Relações Públicas quanto à utilização das mídias digitais. Ou seja, antes das ações de comunicação organizacional integrarem em seu escopo essas mídias é preciso levar em consideração uma série de fatores como: o objetivo de determinada ação, o público que se pretende atingir, o conhecimento do público interno para a utilização dessas ferramentas, a acessibilidade do consumidor a essas mídias e, também, se a própria organização tem condições de manter atualizado um blog, se tem pessoal para monitorar manifestações em espaços digitais, por exemplo. Portanto, fica claro que a utilização estratégica das mídias digitais passa primeiramente pelo filtro da cultura empresarial. Sua utilização 
precisa ser adotada com tranqüilidade e clareza de objetivos. A partir da realidade empírica analisada percebe-se que os usos ainda estão restritos a algumas mídias. Constata-se que a comunicação interna é carente de estratégias digitais, mas também por essa realidade ser marcada profundamente pela cultura organizacional.

É necessária uma mudança de processos, idéias e mentalidades, que coloquem em prática planejamentos que realmente respeitem a cultura da organização, as características e especificidades dos públicos. Essa ponderação se faz imprescindível para fugir do uso pelo uso ou do modismo tecnológico visando apenas resultados imediatos. (WOLTON, 1999) É preciso ponderar a performance tecnológica, que por vezes confunde a acelerada transmissão de informações com a qualidade da comunicação. A generalização na utilização das mídias digitais a fim de potencializar relacionamentos, não significa que se esteja praticando uma comunicação eficaz.

$\mathrm{O}$ fato de se ter apresentado aqui as vantagens das novas mídias como canais de relacionamentos mais dinâmicos, aproximativos e de colaboração, não quer enfatizar uma urgência na utilização dessas estratégias pelas organizações de maneira geral. Acredita-se, sim, que elas venham complementar as estratégias veiculadas nos tradicionais meios de comunicação. O Boticário trabalha com todas essas interações, mas de forma a despertar o interesse e levar as pessoas às lojas físicas. Ou seja, existe a interação mediada pelo computador, mas com vistas à interação face a face.

Muitas vezes o fascínio pelas possibilidades digitais de interação leva à conclusão precipitada de qualidade na comunicação, mas questiona-se: será que elas resolverão os problemas e dificuldades organizacionais? Será que elas facilitarão ou apenas instrumentalizarão a comunicação entre organização e seus públicos? Serão suficientes para atender as necessidades dos consumidores?

Uma visão muito míope e estreita seria pensar na comunicação organizacional a partir apenas das mídias digitais. O que não se pode perder de vista é o objetivo maior dessa comunicação e o entendimento de que a comunicação organizacional - entendida como parte não só da cultura organizacional, mas como um elemento estratégico que se confunde com a própria estratégia da organização-, nos reporta a uma reflexão que supera toda a sorte de reducionismos e práticas instrumentais dos processos comunicativos, como salienta Fossá (2008). Não se pode restringir a estratégia comunicacional à simples produção de instrumentos de comunicação, à práticas de planos, programas e projetos, porque a comunicação organizacional vai além dos limites da instituição para situá-lo no contexto da sociedade.

Desse modo, antes de se redirecionar os relacionamentos organizacionais para a plataforma digital é necessário pensar a estratégia da comunicação como um ato único da estratégia organizacional, ou seja, reforça-se a idéia de uma estratégia de comunicação que agrega valores, possibilita a integração de grupos e pessoas e produz mediações significativas da organização com os seus diferentes públicos. Portanto, a organização para atingir os públicos estratégicos de forma eficaz necessita identificar os melhores canais (sejam eles tecnológicos ou não), adaptar a linguagem e incorporá-los às práticas de planejamento, execução e avaliação da comunicação organizacional.

Da caixa de sugestões às mídias digitais o que se percebe é que ambas são mídias que não se bastam, pois tudo o que deve ser mudado ou substituído é feito a partir do interior da própria organização. Pressupõese, portanto, que os significados do processo comunicativo devem ser estabelecidos e aceitos a priori e assim orientar normas e valores para serem compartilhados entre indivíduos e sistemas sócio-culturais. 


\section{Bibliografia:}

CASTELLS, Manuel. A sociedade em rede. São Paulo: Paz e Terra, 1999.

CIPRIANI, Fábio. Blog corporativo: aprenda a melhorar o relacionamento com seus clientes e fortalecer a imagem da sua empresa. São Paulo: Novatec, 2008.

ECHEVERRIA, Javier. Los Señores Del Aire: Telépolis y el Tercer Entorno. Barcelona: Ediciones Destino, 2004.

FORTES, Waldyr Gutierrez. Relações públicas: processo, funções, tecnologia e estratégias. 2. ed. São Paulo: Summus, 2003.

FOSSÁ, Maria Ivete Trevisan. "Comunicação Organizacional: Confrontos entre Luhmann e Habermas Conjecturas Necessárias”. In: Encontro Nacional dos Programas de Pós-Graduação em Administração. Rio de Janeiro: ENAPAD, 2008.

FOUCAULT, Michel. Vigiar e Punir. Petrópolis: Vozes, 1986.

GRUNIG, James E. e HUNT, Todd. Dirección de Relaciones Públicas. Barcelona: Ediciones Gestión, 2000 S.A, 2003.

IANNI, Octávio. Teorias da Globalização. São Paulo: Editora Civilização Brasileira, 2002.

KEGLER, Jaqueline Quincozes Silva. Comunicação pública e complexidade: uma perspectiva das Relações Públicas como sujeito comunicacional e estratégico no cenário da midiatização. Dissertação Mestrado em Comunicação. Universidade Federal de Santa Maria (UFSM), Santa Maria, 2008.

KUNSCH, M. M. K. . "Comunicação organizacional na era digital: contexto, percursos e possibilidades". Signo y Pensamiento, v. XXVI, p. 38-51, 2007.

LEMOS, André. Cibercultura - Tecnologia e Vida Social na Cultura Contemporânea. Porto Alegre, Sulina, 2002.

LEVY, Pierre. A inteligência coletiva: por uma antropologia do ciberespaço. São Paulo: Loyola, 1999. , Pierre. O que é virtual? São Paulo: Editora 34, 1999.

NETO, Francisco Paulo de Melo. Reengenharia: estudos de caso de empresas brasileiras. Rio de Janeiro: Record, 1995.

ORDUÑA, Octávio L, et al. Rojas. Blogs: revolucionando os meios de comunicação. São Paulo: Thomson Learning, 2007.

PRIMO, Alex. Interação mediada por computador: comunicação, cibercultura, cognição. Porto Alegre: Sulina, 2007. (Coleção Cibercultura).

PRIMO, Alex . Interney blogs como micromídia digital: elementos para o estudo do encadeamento midiático. Contracampo (UFF), v. 19, p. 152-167, 2008.

SANTAELLA, L. Culturas e artes do pós-humano: da cultura das mídias à cibercultura. São Paulo: 
Paulus, 2003.

WOLTON, Dominique. E depois da Internet? Para uma teoria crítica dos novos médias. Portugal: DIFEL, difusão editorial: 1999.

\section{Notas:}

(1) Trabalho apresentado na Divisão Temática DT 03 - Relações Públicas e Comunicação Organizacional do XXXII do Congresso Brasileiro de Ciências da Comunicação (Curitiba-PR, 04-07/09/2009).

(2) http://www2.boticario.com.br/mamiebella/default.aspx acessado em 06 de junho de 2009.

(3) http://www2.boticario.com.br/mundomaisbelo/ acessado em 06 de junho de 2009.

(4) O Boticário, empresa do ramo de cosméticos, iniciou suas atividades como uma pequena farmácia de manipulação no centro da cidade de Curitiba (PR) em 1977. Fórmulas inovadoras, qualidade e relações éticas transformam a pequena farmácia na maior rede de franquias de cosméticos do mundo. Hoje, com fábrica em São José dos Pinhais (PR) ela emprega 1.400 funcionários e tem área construída de 39 mil m². A linha que começou com dois produtos - um creme hidratante e um shampoo à base de algas marinhas conta hoje com cerca de 600 itens, divididos em perfumaria, maquiagem, cuidados para o corpo, cuidados faciais, protetores solares, desodorantes, sabonetes e shampoos.

(5) Segundo Lemos (2004), o ciberespaço configura-se como uma rede social complexa que promove a formação de comunidades, as quais serão potencializadas pela evolução tecnológica.

(6) Para Santaella (2003) e Primo (2008) a palavra "mídia" vem sendo utilizada sem uma preocupação ou determinação de seu sentido imediato, como se o vocábulo fosse transparente. Ainda é recorrente a utilização de "mídia" em referência aos meios de comunicação de massa. "Entretanto, o surgimento da comunicação teleinformática veio trazer consigo a ampliação do poder de referência do termo mídias que, desde então, passou a se referir a quaisquer tipos de meios de comunicação, incluindo aparelhos, dispositivos ou mesmo programas auxiliares da comunicação." (SANTAELLA, 2003: 62) A autora ainda diz que a generalização do termo faz referência a todos os processos de comunicação mediados pelo computador. Neste artigo redes sociais, blogs, microblogs, plataformas musicais ou sites que disponibilizam vídeos e fotos online, serão tratados como espaços de mídias digitais. Entendendo mídia como um canal de comunicação que oferta informações e conteúdos. Desta forma, parte-se do pressuposto que a comunicação organizacional, atuante também no meio digital, pode utilizar esses espaços de forma estratégica.

(7) A partir da solicitação das autoras deste artigo, a empresa disponibilizou alguns materiais, são eles: Plano do Centro de Atendimento ao Consumidor, relatório fornecido pela empresa E-life de julho de 2007 e artigo publicado pelo Boticário divulgando o case Órfãos do One of us.

(8) Levy (1999:15) diz que "a palavra virtual vem do latim medieval virtualis, derivado por sua vez de virtus, força, potência. Na filosofia escolástica, é virtual o que existe em potência e não em ato. [...] O virtual não se opõe ao real mas ao atual: virtualidade e atualidade são apenas duas maneiras de ser diferentes."

(9) Para o autor, o terceiro entorno caracteriza-se como o entorno telemático, eletrônico ou digital. A transformação neste contexto significa a mudança nas categorias de tempo e espaço, levando à construção 
de um novo espaço social. O autor chama de "sobrenatureza" a série de transformações tecnológicas sofridas pela sociedade. Todas essas inovações tecnológicas trazem grande contribuição para a construção desse espaço social e aqui destaca-se a Internet. Ela se apresenta como um meio multidirecional e interativo, provocando uma maior competitividade com os meios clássicos de comunicação e levando outras tecnologias a integrarem-se na rede.

(10) Tradução livre da autora. Do original: "Para estar en Internet hay que construir la página web correspondiente, que es una representación A' de uno mismo (o de la empresa u organización). Se actúa a través de esa imagen tecnológica. Lo importante es que, para actuar em E3, es imprescindible construir diversas representaciones A', y hacerlo bien." (ECHEVERRIA, 2004: 67)

(11) Visibilidade é entendida a partir do conceito formulado por Michel Foucault (1986) que compreende a visibilidade como a tecnologia de cada época que proporciona regimes de luz e dispositivos de reconhecimento.

(12) http://www.tweetquerobeijoboticario.com/ acessado em 07 de junho de 2009.

(13) Segundo o autor, além da interação mútua também existe a interação reativa que se caracteriza como um intercâmbio vigiado e controlado por predeterminações. "Uma pessoa, ao interagir com tal máquina, terá de adaptar-se à formatação exigida, manifestando-se dentro das condições e dos limites previstos". (PRIMO, 2007: 135)

(14) Embora este entendimento de Alex Primo (2007), de interação mútua e reativa, tenha sido pensado a partir da interação mediada pelo computador, aqui se entende que possa haver, também, interação mútua mediada por carta ou por telefone.

(15) Empresa que utiliza métricas e softwares desenvolvidos especialmente para a monitoração e análise das redes sociais, identificando formadores de opinião, com comentários que repercutam em microaudiências, identificando o caminho percorrido pelo boca-a-boca online. http://www.elife.com.br/ acessado em 07 de junho de 2009.

(16) No YouTube são disponibilizados vídeos das blogueiras do Mamie Bella, situações quotidianas, consultas médicas, passeios e dicas de exercícios físicos. Já no Blip.fm são dicas de músicas de ninar e músicas relaxantes. No Flickr são os registros fotográficos dos vídeos do YouTube e de algumas ações promovidas pelo Eu faço um mundo mais belo! .

\section{Mini Currículo :}

Patrícia M. Pérsigo é mestranda em Comunicação Midiática no PPGCOM-UFSM, especialista em Marketing e Recursos Humanos (FAMES) e graduada em Comunicação Social - Relações Públicas(UFSM).

Maria Ivete T. Fossá é professora do Programa de Pós Graduação em Comunicação da UFSM e do Programa de Pós-Graduação em Administração da UFSM. Doutora em Administração pela UFRGS e mestre em Comunicação pela UMESP. 